\title{
Design of automatic control system for the precipitation of bromelain from the extract of pineapple wastes
}

\author{
Desenvolvimento de sistema de controle para precipitação de bromelina a partir de resíduos de abacaxi
}

\author{
Flavio Vasconcelos da SILVA ${ }^{1}$, Regina Lúcia de Andrade dos SANTOS ${ }^{1}$, \\ Tatiana Lie FUJIKI ${ }^{1 *}$, Manuela Souza LEITE ${ }^{1}$, Ana Maria Frattini FILETI ${ }^{1}$
}

\begin{abstract}
In this work, bromelain was recovered from ground pineapple stem and rind by means of precipitation with alcohol at low temperature. Bromelain is the name of a group of powerful protein-digesting, or proteolytic, enzymes that are particularly useful for reducing muscle and tissue inflammation and as a digestive aid. Temperature control is crucial to avoid irreversible protein denaturation and consequently to improve the quality of the enzyme recovered. The process was carried out alternatively in two fed-batch pilot tanks: a glass tank and a stainless steel tank. Aliquots containing $100 \mathrm{~mL}$ of pineapple aqueous extract were fed into the tank. Inside the jacketed tank, the protein was exposed to unsteady operating conditions during the addition of the precipitating agent (ethanol 99.5\%) because the dilution ratio "aqueous extract to ethanol" and heat transfer area changed. The coolant flow rate was manipulated through a variable speed pump. Fine tuned conventional and adaptive PID controllers were on-line implemented using a fieldbus digital control system. The processing performance efficiency was enhanced and so was the quality (enzyme activity) of the product.
\end{abstract}

Keywords: bromelain; PID Controllers; fieldbus.

\section{Resumo}

No presente trabalho, a enzima bromelina foi obtida a partir da casca e do talo do abacaxi, através de precipitação com álcool, com controle de temperatura. Bromelina é o nome de um grupo de enzimas proteolíticas com propriedades anti-inflamatórias e digestivas. O controle de temperatura é fundamental para evitar a desnaturação irreversível da proteína e, consequentemente, aumentar a qualidade da enzima recuperada. O processo foi realizado em duas plantas-piloto: um tanque de vidro e outro de aço-inox. Foram utilizadas alíquotas contendo $100 \mathrm{~mL}$ de caldo de abacaxi nos tanques. Dentro do tanque encamisado, a proteína foi exposta a condições operacionais instáveis durante a adição do agente precipitante (etanol 99,5\%), porque a razão de diluição "caldo de abacaxi: etanol" e a área de transferência de calor eram alteradas. A vazão do fluido refrigerante foi manipulada através de uma bomba de deslocamento positivo. Os controladores convencional e PID adaptativo sintonizados foram implementados online, utilizando um sistema de controle digital Fieldbus. Observou-se uma melhoria no desempenho do processo, assim como na qualidade (atividade enzimática) do produto.

Palavras-chave: bromelina; controladores PID; fieldbus.

\section{Introduction}

In many biotechnological industries, including food and pharmaceutical plants, the selective separation of a protein from fermentation broths or vegetable sources has been a primary research interest for downstream processing operations. It is difficult and expensive to selectively recover a targeted protein from a broth due to the low protein concentration and the similarity of the physical properties between proteins present in the same solution.

Among the practical methods being applied to the largescale recovery and purification of proteins from dilute solution, protein precipitation is regarded as a key operational process, which is used during the early stages of the downstream processing. Protein precipitation is frequently featured by the spontaneous fractionation and concentration as well as a low additive consumption and protein non-denaturation (KIM; HIRASAWA; KIM, 2002; ARAKAWA; YOSHIKO; TIMASHEFF, 2007; HEDHAMMAR; KARLSTRON; HOBER, 2006). Protein precipitation usually produces insoluble protein by contacting precipitants such as neutral salts, acids, organic solvents, or metallic ions with the desired protein in a stirred tank.

The need for rapid monitoring in biotechnology has been highlighted by several authors (FIKSDAL; TRYLAND, 2008; BACKER et al., 2002; LOCHER; SONNLEITNER; FIECHTER, 1992). The highest cost downstream processing steps for manyproducts, which means that if the purification sequence is performed within pre-specified limits for obtainingof high yield, identifying rapidly when such limits are crossed, is an extremely important consideration (DESAI, 2000; HOLWILL et al., 1996). Particularly, for enzyme precipitate products, quality control is mandatory to ensure structural authenticity. If, in addition, prior process knowledge allows feedback control using on-line information, then costly run-stoppage times or disposal of nonspecification material may be avoided (HOLWILL et al., 1996; DOUBLE; KRUTHIVENT, 2007).

Recebido para publicação em 1/12/2008

Aceito para publicação em 14/2/2010 (003976)

Departamento de Engenharia de Sistemas Químicos, Faculdade de Engenharia Química, Universidade Estadual de Campinas - UNICAMP, CEP 13083-970,

Campinas - SP, Brasil, E-mail: tatianafujiki@gmail.com

${ }^{*}$ A quem a correspondência deve ser enviada 
The successful operation and control of bioprocesses require a method by which the process objective can be achieved reliably and quickly. This in turn means that process variables constituting the control law must be measured on-line. Direct on-line measurements of the primary process variables such as the biomass, substrate, and product concentrations are usually not possible due to the lack of suitable measuring devices or probes. The dynamic nature of bioprocess results in varying growth rates, oxygen uptake rate and product formation rates under different operating conditions. This coupled with the inherent nonlinearity of bioprocess makes system identification difficult. Consequently, one of the trends in bioprocess control has been to develop identification strategies based on nonlinear system (GADKAR; MEHRA; GOMES, 2005).

While the fermentation control problem is extensively studied because of its complexity, the practical application of control in downstream processing is considered to a lesser extent. Most bioprocesses are carried out in batch or semi-batch systems, so that their dynamic nature poses a challenging control system design, mainly reflected in fermentation processes. Nonlinearity is usually found in all classes of bioprocesses as well; therefore, conventional feedback controllers are not supposed to be able to follow set-point specifications.

The fixed-parameter conventional Proportional-IntegralDerivative (PID) controller is ubiquitous in the process industries (BEQUETTE, 2003). This controller has the form of Equation 1.

$u(t)=u_{s s}+K_{c}\left[e(t)+\frac{1}{\tau_{i}} \int_{0}^{T} e(t) d t+\tau_{d} \frac{d e(t)}{d t}\right]$

where $K_{c}, \tau_{i}$ and $\tau_{d}$ are controller parameters, respectively: controller gain, integral time, and derivative time. The control action to be implemented is $u(t)$ and its intensity varies with the error between the setpoint and the measured output: $e(t)=c s p$ $c m(t)$. The bias term, $u_{s s}$, is the steady-state action value.

According to Bequette (2003), perhaps the most widely mentioned technique for controlling nonlinear processes is gain scheduling. A major advantage of a parameter-scheduled controller is that linear control system design procedures can be used. Although all of the controller parameters can be scheduled, controller gain is commonly scheduled because processes are often characterized as a changing gain, $K_{p}$, with relatively constant dynamics. An important step in developing this class of adaptive controller is determining the proper scheduling variable. Rules of thumb such as scheduling on a "slow variable" or "using a variable that captures the nonlinearities" are often used. When there are additional measurements, a measured or inferred auxiliary variable, $\alpha$ can be used for scheduling, so that $K_{c}=f(\alpha)$.

From the literature review presented, it can be concluded that since conventional PID controller does not provide good performance for nonlinear and transient systems, an alternative solution could be the use of the so-called adaptive controllers, in which the parameters are variable.

In this work, the design and tuning of conventional PID and adaptive PID controllers was experimentally developed for a pilot batch plant to precipitate enzymes using Single-Input Single-Output (SISO) strategy in fieldbus network architecture. Bromelain was recovered from commercial ground pineapple stem and rind (usually kitchen waste) through the precipitation process with alcohol at low temperature. Enzyme activity assays were carried out in order to determine the most suitable temperature of precipitation, i.e. the setpoint of closed-loop experiments.

Bromelain is the name of a group of powerful proteindigesting, or proteolytic, enzymes that are found in the pineapple plant (Ananas comosus). Discovered in 1957 and widely studied since then, bromelain is particularly useful for reducing muscle and tissue inflammation and as a digestive aid. Besides its pharmacological effects, bromelain is also employed in food industries such as breweries and meat processing.

In the precipitation process studied, bulk temperature control was crucial to avoid the irreversible Bromelain denaturation and consequently to improve the precipitation yield. The coolant flow rate of the jacketed precipitation tank was then manipulated through a variable speed pump driven by a feedback controller. Unsteady operating conditions occurred during the addition of the precipitating agent to the tank because the dilution ratio "aqueous extract to ethanol" and heat transfer area changed. An inferred variable that was able to capture the transient conditions and the nonlinearities of this process was the volume of the mixture. This auxiliary variable was then used for scheduling the gain in the adaptive controller.

A comparative analysis of the fixed-parameters PID and the adaptive PID controllers was were shown based on the performance indexes, such as ITAE, overshoot, and rise time.

The objective of the precipitation process is to achieve separation by the conversion of solutes into solids. Precipitation can result in both concentration and purification methods. The advantages of using precipitation for concentration and purification are: easy scale-up; simple equipment; and a large number of alternative precipitants; some of them are inexpensive or used at a very low concentration. The precipitants should not denaturate biological products, and the precipitate form is often more stable than the solute material.

A larger number of water-miscible organic solvents such as ethanol or methanol can be used to precipitate proteins. A typical globular protein presents a surface consisting of regions of positive and negative charge, along with polar, but uncharged, hydrophilic regions and nonpolar, hydrophobic regions to the solvent. The complex interactions between the protein surface and surrounding solvent determine solubility. A protein is made insoluble by changing either the surface characteristics of the protein itself or by changing the solvent. The change in solubility that results is sufficiently great to be viewed as step change between soluble and insoluble. The resulting high level of supersaturation leads to rapid formation of an amorphous solid.

As in the case of salting-out, this phenomenon has been described in terms of water removal from the hydration spheres of the protein allowing electrostatic forces to bring oppositely charged regions of the protein together. Water is removed by bulk replacement; by the organic solvent; and by the structuring 
of the water around the organic molecules. The solvent property affected is the dielectric constant. The hydrophobic area of the protein would tend to become more soluble, but the net result is a decrease in solubility.

\section{Materials and methods}

\subsection{Fed-batch precipitation tank}

The bromelain precipitation process was carried out in a fedbatch stirred glass tank, according to Figure 1. Overprecipitation is less likely to occur by slowly adding precipitant and dispersing it well. Pineapple extract $(100 \mathrm{~mL})$ makes up the initial volume of the tank. A micropump (pump 1) was used to continuously feed the ethanol $99.5 \mathrm{GL}$, at room temperature (approximately $25^{\circ} \mathrm{C}$ ) and at a fixed rate of $0.57 \mathrm{~mL} / \mathrm{second}$ until the tank reached $500 \mathrm{~mL}$. Inside the jacketed tank, the protein will be exposed to a range of operating conditions during the period in which the precipitant agent (dehydrated ethanol) is added. Variations in heat transfer area (from 120 to $276 \mathrm{~cm}^{2}$ ) and in the ratio "extract to ethanol" (from 1:0 to $1: 4 \mathrm{v} / \mathrm{v}$ ) describes the operational range of the process. As a consequence, the precipitated material will form at different rates.

In order to avoid protein denaturation, the setpoint for bulk temperature was experimentally determined by means of enzyme activity assay (see "Materials and Methods"). The results show an activity of $0.8739 \mathrm{U} \cdot \mathrm{mL}^{-1}$ at $5^{\circ} \mathrm{C}, 0.7478 \mathrm{U} \cdot \mathrm{mL}^{-1}$ at $10^{\circ} \mathrm{C}$, and $0.7204 \mathrm{U} \cdot \mathrm{mL}^{-1}$ at $20^{\circ} \mathrm{C}$. Therefore, the setpoint selected for bulk temperature was $5^{\circ} \mathrm{C}$.
Calibrated PT-100 temperature sensors were located at the precipitation mixture bulk and at the inlet and outlet of coolant (propylene glycol at $-14{ }^{\circ} \mathrm{C}$ ). The coolant flow rate was manipulated through a variable speed pump (pump 2) - see "Calibration of propylene glycol pump" for details. The management of the digital control system was performed through a Foundation Fieldbus communication system. Four field devices made up the fieldbus network used to monitor and control the precipitation tank: Distributed Fieldbus Interface, Temperature Transmitters, and Fieldbus/Electric Current Converter. The digital signal sent to pump 2 was calculated by developed controllers.

\subsection{Pineapple extract preparation}

Fifteen commercial pineapples (species "Perola") were bought from the same place in order to keep the samples uniform. Stem and rind of pineapple fruits were ground and mixed to get a uniform aqueous extract. Distilled water was used at a dilution rate of 1:1 v/v. Solids were filtered out from the mixture by means of paper filters (slow flow rate, with good retention for small particles; $2.5 \mu \mathrm{m}$ ). The filtrate, called pineapple extract, contains the bromelain enzyme. Aliquots containing $100 \mathrm{~mL}$ of pineapple extract were frozen at $-18{ }^{\circ} \mathrm{C}$ (CESAR; SILVA; LUCARINI, 1999) until they were individually used in the experiments (limited period of three months). The average total protein content (FREIMAN; SABAA SRUR, 1999) of this pineapple extract was approximately $0.8358 \pm 0.0194 \mathrm{mg} \cdot \mathrm{mL}^{-1}$ at $\mathrm{pH} 7.0$.

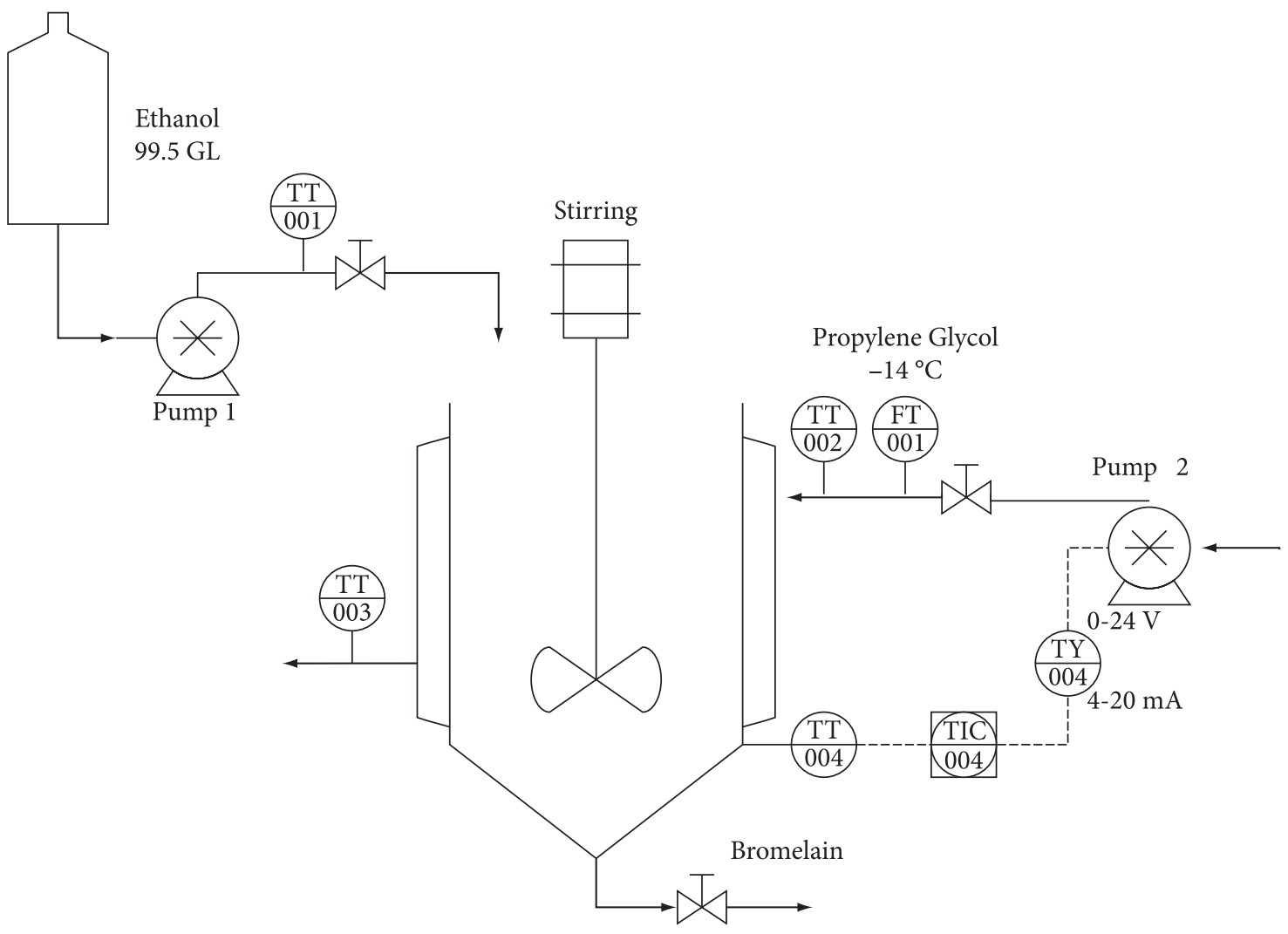

Figure 1. Fed-batch stirred precipitation tank. 


\subsection{Enzyme activity assay}

Enzyme activity was determined by enzymatic hydrolysis of casein $2 \%(\mathrm{w} / \mathrm{v})$ at $\mathrm{pH} 7.5$, temperature $37^{\circ} \mathrm{C}$, for 10 minutes. Tricloroacetic acid (TCA) was used in the precipitation of the non-hydrolyzed product. The amount of soluble peptides in TCA was determined by measuring the absorbance at $280 \mathrm{~nm}$. The method defines one unity of enzyme activity as the amount of enzyme that modifies the absorbance in 1.0 at $280 \mathrm{~nm}$.

\subsection{Calibration of propylene glycol pump}

The coolant flow rate was manipulated through a variable speed pump. This pump operated at a voltage rate input signal $(0-24 \mathrm{~V})$. The greater the voltage, the greater the speed and the flow rate. The controller implemented in the digital control system calculated the voltage increment and the converter device drove the pump. The relationship between flow rate and percentage of maximum speed (or voltage) is shown in Figure 2.

\subsection{Controller tuning (open-loop)}

\section{Conventional PID}

The well-known and widely used first method of ZieglerNichols was used for PID tuning purposes. A pseudo-steady state condition was experimentally simulated by adding and withdrawing pineapple extract at the same rate. In this experiment, the pineapple extract was diluted with ethanol (1:2) in order to maintain the same batch precipitation conditions at $300 \mathrm{~mL}$. The inlet coolant temperature was fixed at $-14^{\circ} \mathrm{C}$ and pump 2 operated at $50 \%$ maximum speed capacity. Keeping these operating conditions, guaranteed that the initial bulk temperature was close to $5^{\circ} \mathrm{C}$ when the fixed rate addition of the ethanol began. At that time, the speed of pump 2 was disturbed (from 50 to $80 \%$ of the maximum capacity). The system was monitored until the bulk temperature reached a new steady-state condition. The data obtained from this process reaction curve procedure was then analyzed and the process parameter gain, time constant, and time delay $\left(K_{p}, T\right.$ and $\left.L\right)$ were calculated by

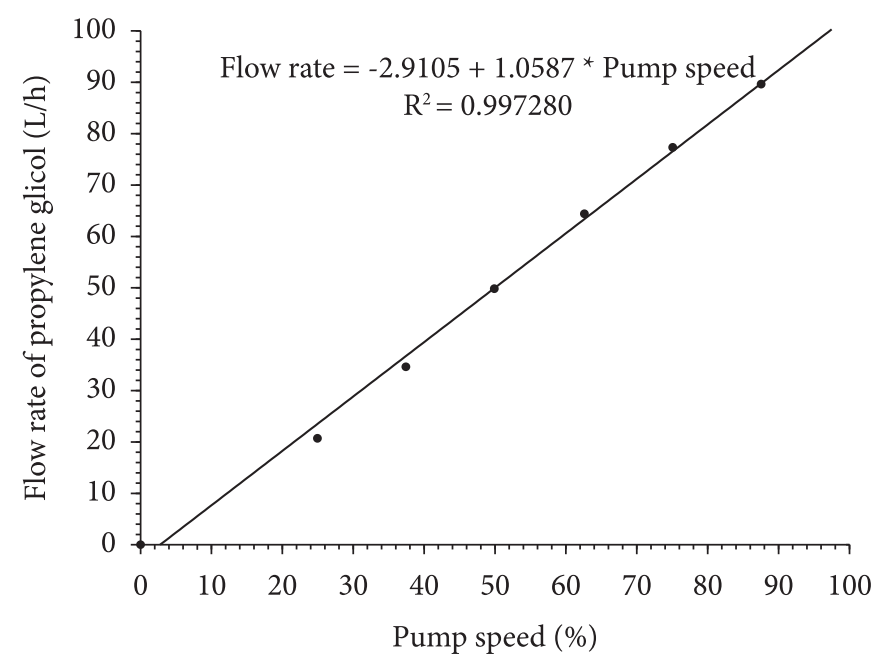

Figure 2. Pump 2 calibration. means of the nonlinear fitting tool of Statistica software ${ }^{\circledR}$ version 7.0. The reaction curve was similar to a first-order process combined with a time-delay and had the transfer function described by Equation 2 . The PID parameters $\left(K_{e} \tau_{i}\right.$ and $\left.\tau_{d}\right)$ were determined using the Ziegler-Nichols tuning equations.

$G p(s)=\frac{K_{p} e^{-L s}}{T s+1}$

\section{Adaptive PID}

In fact, the volume and consequently the heat transfer area changed during the batch precipitation process. Due to this transient nature and process nonlinearity, the parameters $K_{p}$ $T$, and $L$ were not constant. Consequently, the PID parameters should be adjusted during the batch.

In order to improve the design of the PID linear controller, Ziegler-Nichols tuning equations were then applied to five reaction curves obtained from different pseudo-steady state volume conditions: $100,200,300,400$, and $500 \mathrm{~mL}$. The procedure was similar to that used in conventional PID tuning.

From this methodology, an adaptive PID controller was obtained in which the gain was scheduled as a function of the volume during the batch operation. The volume determination was given by: "batch time multiplied by ethanol flow rate plus initial volume of the tank".

\subsection{Stability analysis}

The closed-loop stability analysis was performed based on the open-loop reaction curve procedure previously described. Once the first-order plus time delay parameters were determined, a root locus diagram was built considering a proportional controller implemented. Ultimate values of gain $K_{c}$ were determined. Since the sampling frequency was very high, Laplace domain was used. The closed-loop characteristic equation used to find pole placement in the complex plane as a function of $K_{c}$ was given by Equation 3:

$1+K_{c} G p(s)=0$

\section{Results}

\subsection{Controller tuning}

\section{Conventional PID}

Figure 3 shows the process reaction curve in which the voltage for pump 2 was disturbed from 50 to $80 \%$ of the maximum capacity for the $300 \mathrm{~mL}$ volume condition. Fitting experimental data of temperature error into a S-shaped curve by means of the nonlinear fitting tool of Statistica software ${ }^{\circ}$ and using a first-order plus time delay model (FOPDT), the process parameters $\left(K_{p}, T\right.$ and $\left.L\right)$ were graphically obtained.

The conventional PID controller parameters were computed through the classical Ziegler-Nichols tuning equations and are summarized in Table 1. 


\section{Adaptive PID}

According to the procedure described in item 3.4, Figure 4 shows the results of the process reaction curves when different initial conditions of volume were employed.

Table 2 summarizes the graphical values of the process parameters as well as the respective computed controller gain $\left(K_{c}\right)$.

It could be noted from the open-loop experimental tests that the behaviour of the system at 100 and $200 \mathrm{~mL}$ volumes was different from the others (300, 400 and $500 \mathrm{~mL}$ ). As previously described, as soon as the volume increases, the proportion of aqueous extract to ethanol decreases (1:0, 1:1, 1:2, 1:3 and $1: 4 \mathrm{v} / \mathrm{v}$ ). At the volume of $100 \mathrm{~mL}$ (pure pineapple extract), the dissolution heat of the alcohol in the aqueous extract is greater than the capacity of the cooling jacket to remove this heat. This was mainly due to the reduced area of heat transfer. Consequently, the load disturbance effects hid the coolant flow rate disturbance and the process reaction curve did not work properly (first and second rows in Table 2). For these two conditions, the values of $K_{c}$ were estimated from the curve fitting in Figure 5.

It can be observed in Figure 5, that the controller gain decreased as soon as the tank volume increased. In fact, the process became more sensitive since the heat transfer area

Table 1. Conventional PID parameters.

\begin{tabular}{lccc}
\hline \multicolumn{1}{c}{ PID parameters } & $K_{c}\left(\% /{ }^{\circ} \mathrm{C}\right)$ & $\tau_{i}(s)$ & $\tau_{d}(s)$ \\
\hline Ziegler-Nichols equations & $=\frac{1.2 T}{K_{p} L}$ & $=2 \mathrm{~L}$ & $=0.5 \mathrm{~L}$ \\
& -223.3 & 26 & 6.5 \\
\hline
\end{tabular}

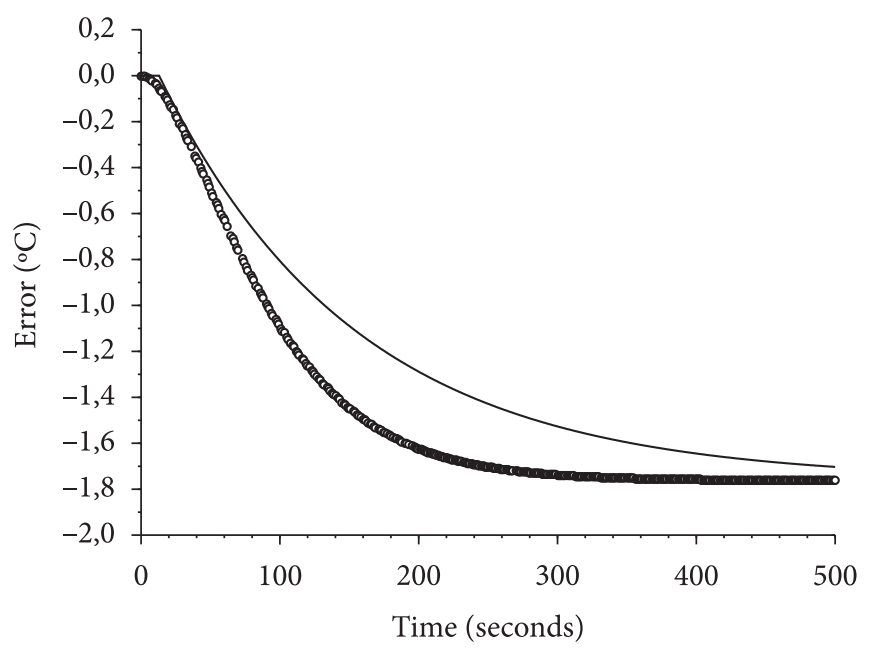

$$
\begin{aligned}
& \text { - Experimental data }- \text { FOPDT Model } \\
& \text { Process gain }(\mathrm{Kp})=-0.059{ }^{\circ} \mathrm{C} / \% \\
& \text { Time delay }(\mathrm{L})=13 \text { seconds } \\
& \text { Time constant }(\mathrm{T})=142 \text { seconds }
\end{aligned}
$$

Figure 3. Process reaction curve used in the conventional PID controller tuning. increased. As a consequence, a small control action was required to regulate the bulk temperature at the end of the batch.

\subsection{Stability analysis}

The ultimate values of the gain $K_{c}$ were determined using Equation 3 and also using the process parameters presented in Table 2. The root locus plot is shown in Figure 6 for conditions of $300 \mathrm{~mL}$ volume. Table 3 summarizes all ultimate values. Following the second tuning method of Ziegler-Nichols, the use of $60 \%$ of the ultimate values as initial guesses for the controller gains (Table 3 ) was also tested. It could be seen that the $K$-values calculated by means of the first method of ZieglerNichols (Table 2) were very similar to those obtained from the second method.

\subsection{Closed-loop experiments}

Pineapple aqueous extract $(100 \mathrm{~mL})$ made up the initial volume of the precipitation tank. A micropump (pump 1) was used to continuously feed the ethanol $99.5 \mathrm{GL}$, at room temperature, until the tank reached $500 \mathrm{~mL}$.

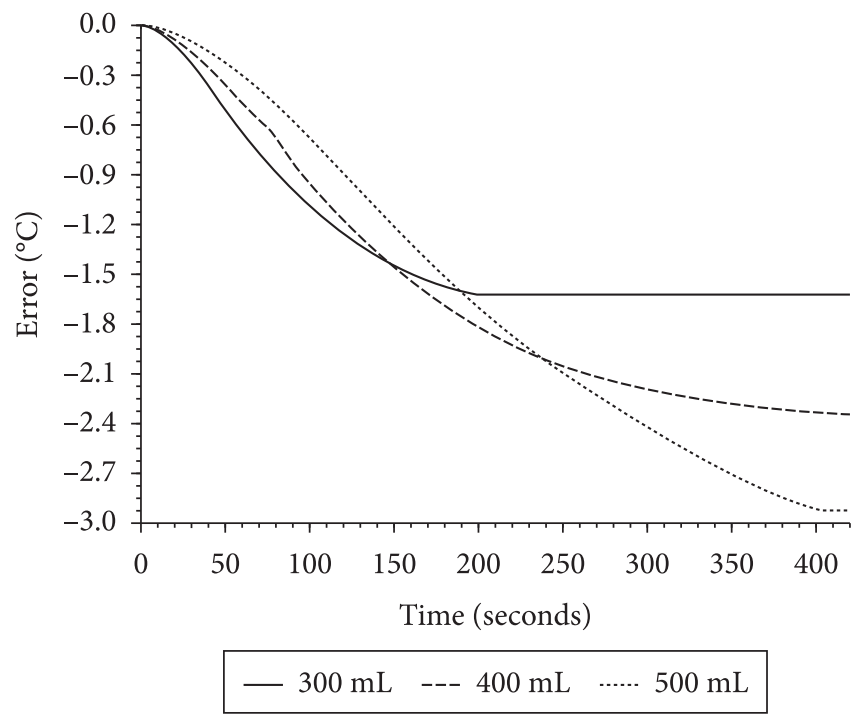

Figure 4. Process reaction curves used in the adaptive PID controller tuning.

Table 2. Process parameters and respective PID gain.

\begin{tabular}{ccccc}
\hline $\begin{array}{c}\text { Volume } \\
(\mathrm{mL})\end{array}$ & $\begin{array}{c}\text { Process gain }\left(\mathrm{K}_{\mathrm{p}}\right) \\
\left({ }^{\circ} \mathrm{C} / \%\right)\end{array}$ & $\begin{array}{c}\text { Time delay }(\mathrm{L}) \\
(\mathrm{s})\end{array}$ & $\begin{array}{c}\text { Time constant }(\mathrm{T}) \\
(\mathrm{s})\end{array}$ & $\begin{array}{c}K_{c} \\
\left(\% /{ }^{\circ} \mathrm{C}\right)\end{array}$ \\
\hline 100 & $*$ & $*$ & $*$ & -599.32 \\
200 & $*$ & $*$ & $*$ & -378.34 \\
300 & $-\frac{1.76}{30}=-0.059$ & 13 & 142 & -223.30 \\
& & & & \\
400 & $-\frac{2.30}{30}=-0.077$ & 21 & 190 & -141.61 \\
500 & $-\frac{2.76}{30}=-0.092$ & 35 & 258 & -96.15
\end{tabular}

${ }^{\star}$ Process reaction curve did not work properly (see text below). 
The flow rate of ethanol was set at $0.57 \mathrm{~mL} / \mathrm{second}$ as the open-loop error of temperature was considered acceptable (Figure 7).

Several experimental tests were carried out using the conventional PID with different tunings in a trial-and-error procedure. Table 1 shows the initial guesses for the controller gain $\left(K_{c}\right)$ and for the integral $\left(\tau_{i}\right)$ and derivative time $\left(\tau_{d}\right)$. From these experiments, it was observed that an increase in the integral time parameter was necessary to avoid long periods of controller saturation. Likewise, decreasing the controller gain improved the performance of the controller in terms of time integral, overshoot, and rise time.

Figure 7 shows the temperature behaviour under well-tuned conventional PID controller $\left(K=-20.76 \% /{ }^{\circ} \mathrm{C}, \tau_{i}=457\right.$ seconds and $\tau_{d}=3.2$ seconds). The ethanol inlet at room temperature, the volume, and the heat transfer area variations were inherent disturbances which drove the process away from the setpoint.

In the early moments of ethanol addition, there was a reduced area of heat transfer because of the low level of the mixture. The impact of the dissolution heat of the alcohol in the pure extract was great at that time. Bulk temperature increased and immediately the control system boosted pump speed. As a consequence of this control action coupled to the decrease in heat generation, temperature decreased too fast and inverse response behaviour was obtained. Soon afterwards, the controller implemented a minimum coolant flow rate, which is the correct action to be taken because heat sources were not enough to raise the temperature anymore.

In the adaptive control, the equation of $K_{c}$ as a function of the volume of the tank (Figure 5), found by means of the first method of Ziegler-Nichols, was implemented through the supervisory system. It is well-known from the literature that this method supplies controller designers with first guesses parameters and that they tend not to be very robust; that is, a small change in the process parameters can cause the closedloop system to become unstable. In order to get fine tuned $K_{c}$-values, another set of closed-loop experiments was carried out in which overshoot, rise time, and ITAE were observed. In this process, called "fine tuning", a correction factor of $1 / 7.5$ was found so that it assures process stability and high performance of the controller. The integral and derivative time remained the same used in the well-tuned conventional PID.

The results are shown in Figure 8. It could be seen that this controller also implemented a minimum coolant flow rate for a long period. As previously explained, at this stage, the lack of heat sources forces the controller to stop cooling the system.

In order to compare conventional and adaptive PID controllers, Figure 9 shows the process behaviour under well-

Table 3. Ultimate values of the controller gain (negative values).

\begin{tabular}{ccc}
\hline Volume $(\mathrm{mL})$ & $\mathrm{K}_{\text {ultimate }}\left(\% /{ }^{\circ} \mathrm{C}\right)$ & $\mathrm{K}_{\mathrm{c}}\left(60 \%\right.$ of $\left.\mathrm{K}_{\text {ultimate }}\right)\left(\% /{ }^{\circ} \mathrm{C}\right)$ \\
\hline 100 & - & - \\
200 & - & - \\
300 & 385 & 231.0 \\
400 & 245 & 147.0 \\
500 & 173 & 103.8 \\
\hline
\end{tabular}

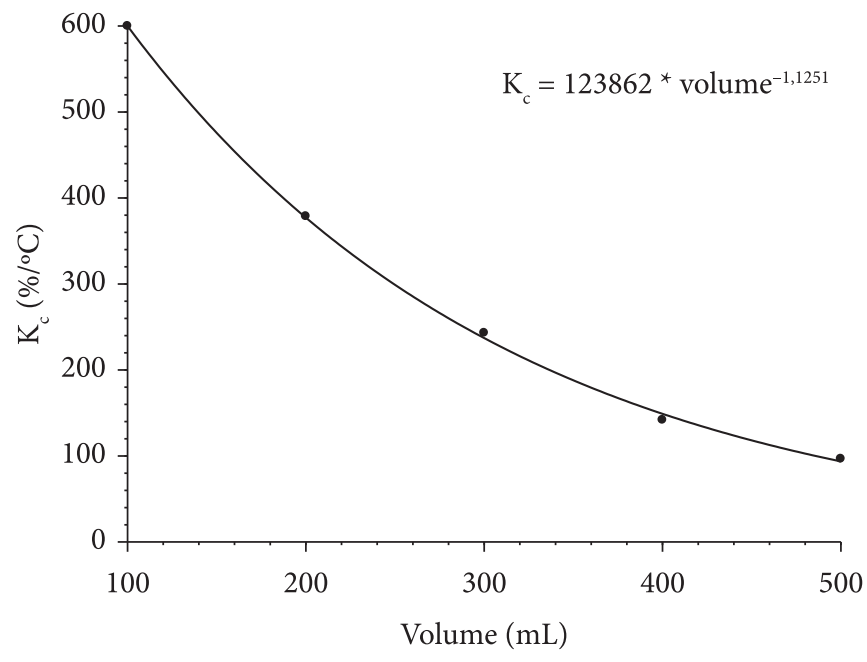

Figure 5. Controller gain $(K c)$ as a function of the volume of the tank.

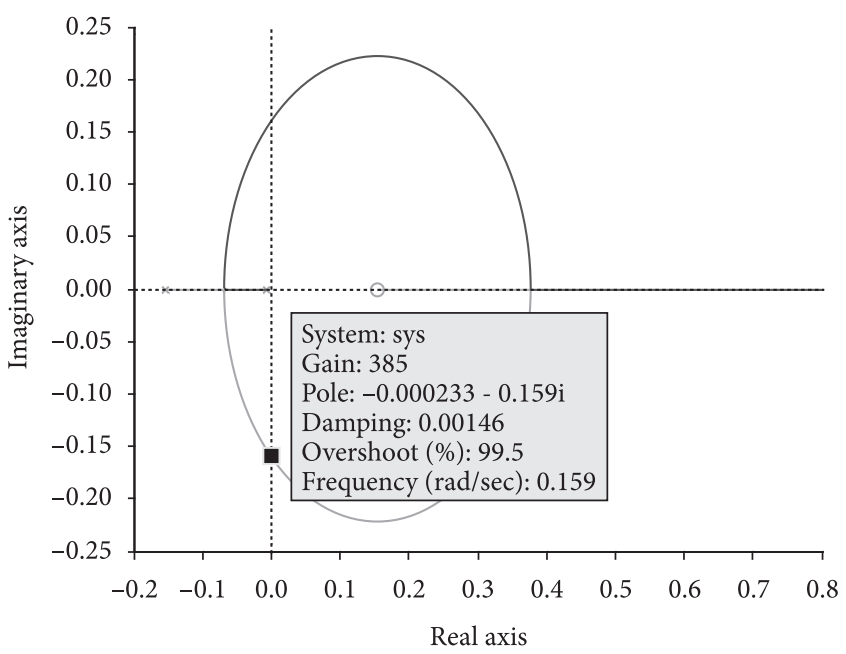

Figure 6. Roots of the characteristic equation as a function of $K_{c}$ (volume $=300 \mathrm{~mL}$ ). Ultimate gain was indicated over the imaginary axis.
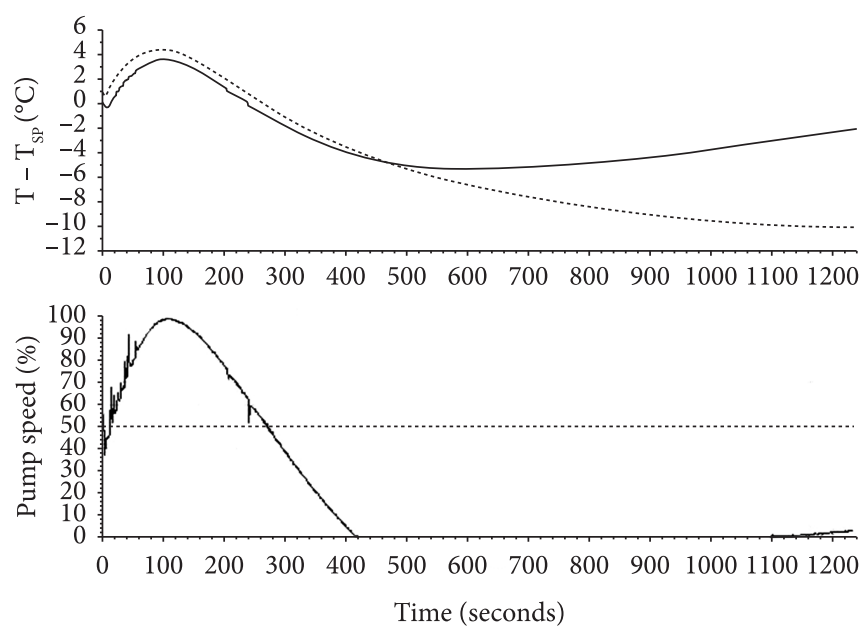

$$
\text { — Convencional PID controller -..... Open-loop }
$$

Figure 7. Bulk temperature error $\left(\mathrm{T}-\mathrm{T}_{s p}\right)$ and manipulated variable behaviour obtained from experimental runs: open-loop and conventional PID implementation $\left(K_{c}=-20.76 \% /{ }^{\circ} \mathrm{C}, \tau_{i}=457\right.$ seconds and $\tau_{d}=3.2$ seconds). 
tuned conventional and adaptive PID. The performance criteria were computed from those experimental runs in Figure 9 and then summarized in Table 4.

Because of the decrease in enzyme activity with temperature, reported in the present work, the overshoot was considered the most important performance index. From this point of view and taking into account that the coolant inlet temperature was fixed, it could be concluded that keeping the pump at maximum speed in the early moments of ethanol addition (Figure 7) was a correct action. The effect of the controller saturation was noted only from 100 to 130 seconds time approximately, after the maximum value was reached and temperature began to move towards the setpoint.

From the results, it could be concluded that the control system was not able to keep the temperature of the precipitation tank at the setpoint value. At the end of the run, there was no heat enough to raise the bulk temperature. Consequently a prolonged period of negative deviations occurs.

\subsection{Process intensification}

In order to enhance the processing performance efficiency, the glass tank was replaced by a geometrically similar stainless steel tank. Once the thermal conductivity of the steel is approximately 20 times greater than the glass conductivity, a more suitable heat exchange was expected. Looking for a way of minimizing energy waste, the temperature of the cooling fluid (propylene glycol) was set at $0{ }^{\circ} \mathrm{C}$ instead of $-14{ }^{\circ} \mathrm{C}$, as used previously. As a consequence of these process adjustments, the value of the process gain became half of the previous one (new $K_{p}=-0.030^{\circ} \mathrm{C} / \%$ ) resulting in a less sensitive process. A new conventional PID was designed based on the procedure described in the Section 3.4. The best settings obtained were: $K_{c}=-35.0 \% /{ }^{\circ} \mathrm{C}, \tau_{i}=28.0$ seconds, and $\tau_{d}=7.0$ seconds.

The pump speed was set to $50 \%$ for the open loop test. It was observed from Figure 10 that open loop negative deviations decreased in comparison to Figure 8, saving energy and helping the control system to keep the set point value.

From the analysis of the performance criteria, it could be concluded that the conventional PID controller kept the temperature closer to the setpoint which is important for the enzyme activity recovery since it is highly sensitive to temperature changes (Table 5). With the PID controller, the total power consumption was $21 \%$ of the open loop energy consumption providing a significant reduction of operating costs.

Table 4. Conventional and adaptive PID performance criteria from experimental runs.

\begin{tabular}{lcc}
\hline \multirow{2}{*}{$\begin{array}{c}\text { Performance } \\
\text { criteria }\end{array}$} & \multicolumn{2}{c}{ Controller } \\
\cline { 2 - 3 } & Adaptive PID & Conventional PID \\
\hline ITAE & $1,945,209.23$ & $2,994,857.64$ \\
Overshoot $\left({ }^{\circ} \mathrm{C}\right)$ & 2.9 & 3.7 \\
Rise time (seconds) & 197 & 241 \\
\hline
\end{tabular}

Table 5. Performance criteria from experimental runs.

\begin{tabular}{lcc}
\hline \multicolumn{1}{c}{$\begin{array}{c}\text { Performance } \\
\text { criteria }\end{array}$} & \multicolumn{2}{c}{ Stainless steel tank } \\
\cline { 2 - 3 } & Open loop & $\begin{array}{c}\text { Conventional } \\
\text { PID }\end{array}$ \\
\hline Overshoot $\left({ }^{\circ} \mathrm{C}\right)$ & 5.0 & 3.1 \\
Rise time (second) & 281 & 171 \\
Enzyme activity $\left(\mathrm{U}^{-1}\right)$ & 0.32 & 1.03 \\
Electric energy consumption $(\mathrm{kWh})$ & 42 & 9.1 \\
\hline
\end{tabular}

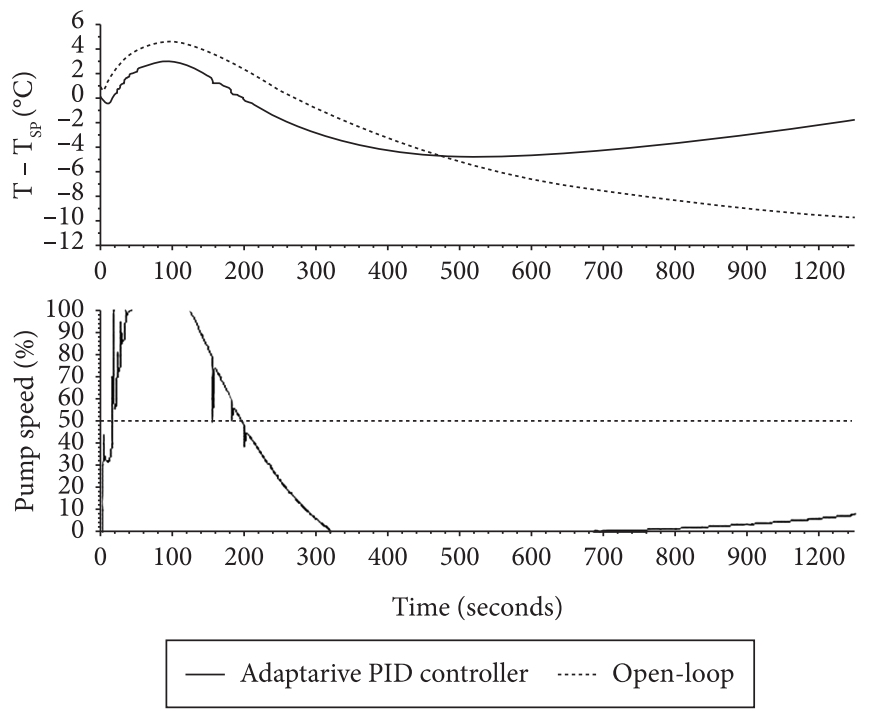

Figure 8. Bulk temperature error $\left(\mathrm{T}-\mathrm{T}_{s p}\right)$ and manipulated variable behaviour obtained from experimental runs: open-loop and adaptive PID implementation $\left(K\right.$ from -80.22 to $-13.28 \% /{ }^{\circ} \mathrm{C}, \tau_{i}=457$ seconds and $\tau_{d}=3.2$ seconds)

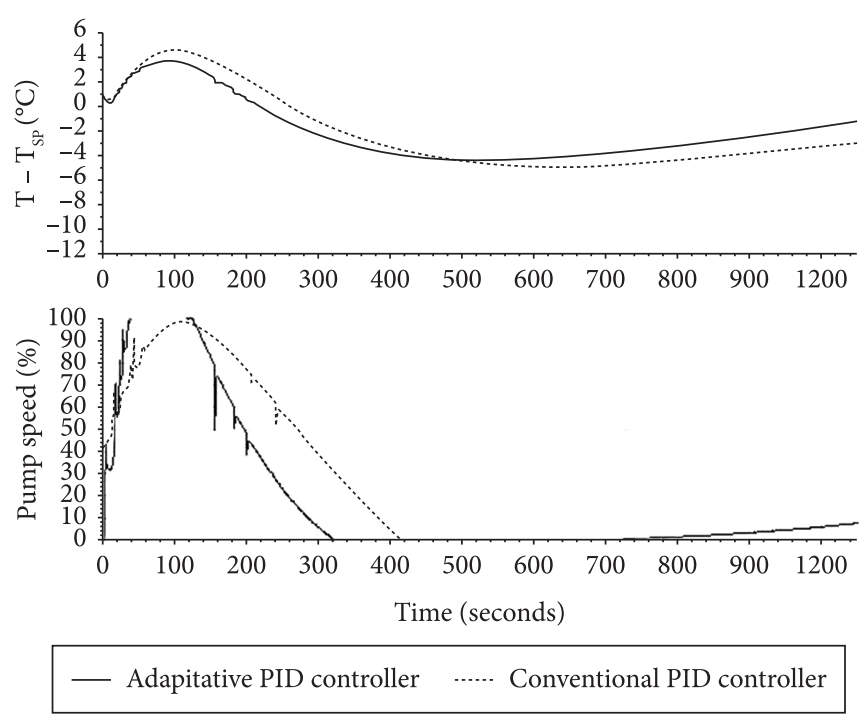

Figure 9. Bulk temperature error $\left(\mathrm{T}-\mathrm{T}_{s p}\right)$ and manipulated variable behaviour obtained from experimental runs: conventional and adaptive PID implementation. 



Figure 10. Bulk temperature error $\left(\mathrm{T}-\mathrm{T}_{s p}\right)$ and manipulated variable behaviour obtained from experimental runs at the stainless steel tank (PID settings: $\mathrm{K}_{\mathrm{c}}=-35.0 \% /{ }^{\circ} \mathrm{C}, \tau_{\mathrm{i}}=28.0$ seconds, and $\tau_{\mathrm{d}}=7.0$ seconds).

\section{Conclusions}

The present work addresses the temperature control problem of bromelain recovery from pineapple stem and rind in pilot plants through precipitation with alcohol at low temperature. The temperature control was achieved using a conventional PID controller tuned for the early stage conditions of the batch and an adaptive PID controller, in which the gain was scheduled as a function of the volume during the batch: the gain decreased as the auxiliary variable, volume, increased.

From the experimental results, a prolonged period of negative deviations occurred under both conventional and adaptive PID controllers. Indeed, the control system was not able to keep the temperature of the precipitation tank at the setpoint value. Looking for a way of enhancing heat exchange and minimizing energy waste, the glass made tank was replaced by a similar stainless steel tank. The temperature of the cooling fluid was changed to $0^{\circ} \mathrm{C}$ instead of $-14^{\circ} \mathrm{C}$, as well. Consequently, the open loop deviation decreased and a suitable conventional PID was achieved. The processing performance efficiency was enhanced and so was the quality (enzyme activity) of the product.

The management of the digital control system was successfully performed through a Foundation Fieldbus communication system. Four intelligent field devices made up the fieldbus network used to monitor and control the precipitation tank. The same fieldbus network was used simultaneously to monitor other chemical system devices of the laboratory but no communication problems arose.

\section{Acknowledgments}

$$
\text { CNPq and CAPES. }
$$

\section{References}

ARAKAWA, T.; YOSHIKO, K.; TIMASHEFF, S. Protein precipitation and denaturation by dimethyl sulfoxide. Biophysical Chemistry, v. 131, n. 1-3, p. 62-70, 2007.

BACKER, K. N. et al. Rapid monitoring of recombinant protein products: a comparison of current technologies. Trends in Biotechnology, v. 20, n. 4, p. 149-156, 2002.

BEQUETTE, B. W. Process control: modelling, design, and simulation. New Jersey: Prentice Hall, 2003.

CESAR, A. C.; SILVA, R.; LUCARINI, A. C., Pineapple stem and rind proteolytic enzymes recovery (In Portuguese). Revista de Iniciação Científica, v. 1, p. 47-53, 1999.

DESAI, M. Downstream processing of proteins: methods and protocols. France: 2000. p.1-10. (Methods in Biotechnology, 9).

DOUBLE, M.; KRUTHIVENT, A. K. Green, chemistry and engineering. India: Elsevier Science and Technology, 2007. 320 p.

FIKSDAL, L; TRYLAND, I. Application of rapid enzyme assay techniques for monitoring of microbial water quality. Environmental Biotechnology, v. 19, p. 289-294, 2008.

FREIMAN, L. O.; SABAA SRUR, A. U. O., Determination of total protein and aminoacid composition of bromelain extracted from pineapple plant residues (Ananás Comosus, (L.) Merril). Ciência e Tecnologia de Alimentos, v. 19, n. 2, 1999.

GADKAR, K. G.; MEHRA, S.; GOMES, J. On-line adaptation of neural networks for bioprocess control. Computers \& Chemical Engineering, v. 29, p. 1047-1057, 2005.

HEDHAMMAR, M.; KARLSTRON, A. E.; HOBER, S. Chromatographic methods for protein purification. Stockholm: Royal Institute of Technology, 2006.

HOLWILL, I. et al. Rapid analysis of biosensor data using initial rate determination and its application to bioprocess monitoring. Process Control and Quality, v. 8, n. 4, p. 133-145, 1996.

KIM, W.-S.; HIRASAWA, I.; KIM, W.-S. Aging characteristics of protein precipitates by polyelectrolyte precipitation in turbulently agitated reactor. Chemical Engineering Science, v. 57, p. 4077-4085, 2002.

KIM, W.-S.; HIRASAWA, I.; KIM, W.-S. Effects of experimental conditions on the mechanism of particle aggregation in protein precipitation by polyelectrolytes with a high molecular weight. Chemical Engineering Science, v. 56, p. 6525-6534, 2001.

LOCHER, G.; SONNLEITNER, B.; FIECHTER, A. On-line measurement in biotechnology: techniques. Journal of Biotechnology, v. 25, p. 23-53, 1992. 